\title{
Memoria en la neblina. Los orígenes chinos de la familia Yeckting en el Perú
}

\section{RESUMEN}

El artículo es un recorrido por la memoria personal y familiar que recoge información, testimonios y entrevistas sobre el origen chino del apellido paterno de la autora. Presenta como punto de partida la migración de su bisabuelo, explorando la vida social de tres generaciones, para identificar las raíces e identidad que ha heredado y conserva su familia en los tiempos actuales.

Palabras clave: Identidad, memoria, migración china, historia familiar, tusanes

\section{Memory in the mist. The chinese origins of the Yeckting family in Peru}

\begin{abstract}
This paper is a journey through personal and family memory that gathers information, testimonies and interviews about the chinese origin of the author's last name. As the starting point, the migration of her great-grandfather is presented, then the social life of three generations is explored in order to identify the roots and identity that the Yeckting family has inherited and still preserves in current times.
\end{abstract}

KEYwORDs: Identity, memory, chinese migration, family history, tussans 


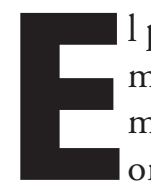
presente artículo es un recorrido por la memoria personal y familiar que recoge información, testimonios y entrevistas sobre el origen chino de mi apellido paterno. Es, a su vez, el inicio de un proyecto personal de búsqueda de mis orígenes en la cultura y tradición china. Tiene por objetivo iluminar aspectos de la historia de mi familia paterna, a través de tres generaciones: la de mi bisabuelo, mi abuelo y mi padre. Con ello busco identificar las raíces e identidad heredados a través de la tradición de la cultura china a través de la memoria y los recuerdos de mi familia. Lo titulé memoria en la neblina, por varias razones. La primera es porque la memoria sobre nuestros orígenes chinos ha estado envuelta en una especie de nebulosa, ya que en mi familia la discreción se utilizaba para casi no hablar a los demás de nuestros orígenes chinos, y sólo algunos pocos aspectos han constituido una línea de continuidad en cuanto a tradiciones o costumbres chinas, que son las que analizo en este texto. Segundo, esa neblina se ha ido despejando al buscar información y conversar con mis tíos y tías sobre sus memorias y entender que la discriminación de la época hacia los migrantes asiáticos, especialmente los chinos, fue una de las razones para no comunicar sus orígenes. Tercero, para que, a la luz de los años, las hipótesis sobre el origen chino de mi bisabuelo, abuelo y padre en este artículo, forme parte de las contribuciones de las nuevas generaciones de tusans, como una forma de la valoración de nuestra existencia como originarios de una cultura milenaria como la china.

Las memorias se reconstruyen como hechos históricos. Tomando a Paul Ricoeur conferimos valor a los hechos anteriores, en ellos está lo que recordamos u olvidamos. Nada mejor que la memoria para garantizar que algo ocurrió antes que nos formásemos el recuerdo de ello (Ricoeur 2004:23). Asimismo, no tenemos nada mejor que la memoria para significar que algo tuvo lugar, sucedió, ocurrió, antes de que declaremos que nos acordamos de ello (Ricoeur 2004: 41).

La memoria además, es colectiva, porque no recordamos solos o individualmente. Afirma Ricoeur, tomando a Halbwachs, que, del testimonio de los otros en la rememoración del recuerdo, se pasa así gradualmente a los de los recuerdos que tenemos en cuanto miembros de un grupo; y que exigen de nosotros un desplazamiento del punto de vista del que somos eminentemente capaces. Accedemos así a acontecimientos reconstruidos para nosotros por otros distintos de nosotros (Ricoeur 2004 p. 158). También hay una distinción entre la memoria y la historia. Según Ricoeur, los historiadores preguntan a los documentos. Para él, las dificultades a las que debe enfrentarse el historiador del pasado reciente dan vida de nuevo a las interrogaciones anteriores sobre el trabajo de memoria, y más aún al trabajo de duelo. Todo sucede como si una historia demasiado próxima impidiese a la memoria-recuerdo librarse de la memoria-retención, y al pasado, separarse sencillamente del presente (Ricoeur 2004 p. 439).

Es por ello que mucho de lo recordado en este texto se analizará en el marco de las memorias colectivas y familiares que a través de mi historia personal han motivado más de una reflexión sobre mis orígenes y el de mis antepasados. Sin embargo, estas reflexiones tienen la influencia de un pasado demasiado reciente y; a la vez, ciertamente lejano, en la medida en que algunos de los personajes que menciono no los conocí sino a través de los recuerdos de los miembros de mi familia. Sin embargo, a otros si los conocí, pero la percepción que tuve de sus personalidades puede distorsionar la interpretación de sus orígenes chinos en la memoria que intento reconstruir.

Los documentos son de una gran ayuda para contrastar dichas percepciones, pero la información que contienen está sujeta a interpretaciones, en la medida que son producto de su tiempo y que no ha habido una reflexión previa sobre el tipo de datos que contienen. Por ello, relataré lo que he encontrado en la memoria familiar a través de los documentos y el testimonio de mis parientes por la línea paterna, especialmente mi tío y mis tías. Los aspectos que abordaré en este texto son: los orígenes: bisabuelo, abuelo y padre; recuerdos de la oficina de mi abuelo y de mi padre (como un lugar de memoria); la contabilidad como trabajo y la transmisión del conocimiento del ábaco; y finalmente, los recuerdos de mi padre y sus tradiciones de origen chino. A manera de epílogo, buscaré concluir sobre cuáles han sido los aspectos más relevantes de dichas memorias para la comprensión de la importancia de las raíces de las tradiciones chinas en mi familia. 


\section{Los orígenes: bisabuelo, abuelo y padre}

Soy la bisnieta de un comerciante de origen chino que probablemente trabajó como secretario o estuvo vinculado al consulado chino en el Perú y que llegó al Perú en 1863. Él se instaló para quedarse a vivir en este país donde se casó con una peruana, quien al parecer también fue descendiente de una familia de origen chino. Con ella tuvo tres hijos $^{1}$. Mi bisabuelo, según la partida de nacimiento de mi abuelo, el documento más antiguo encontrado que es de $1890^{2}$, sostiene que era un súbdito chino, natural de Tong Gan departamento de Fsuen Tcheon de la provincia de Fonkien (Fukien). Los lugares de origen que aparecen en este documento pueden haber sufrido algún cambio o distorsión porque no coinciden con la información que aparece en documentos posteriores.

Un documento de la Legación de China ${ }^{3}$ certifica que el señor Carlos Chang Yekting de 67 años, profesión comerciante, casado; también domiciliado en el Perú desde el año 1863, en Lima, en la calle de Hoyos No. 605, está registrado como ciudadano chino. La foto de la inscripción del documento figura como 1876. Este período corresponde a la segunda gran etapa de la inmigración china que comenzó a finales del siglo XIX. En él, tanto los inmigrantes chinos que trabajaban en las haciendas como los que establecieron en diversas ciudades como comerciantes o artesanos, superaron gradualmente las dificultades planteadas por la marginación social, los prejuicios, las diferencias culturales, el problema del lenguaje. Desde allí comienza el verdadero proceso de fusión cultural entre los migrantes chinos y peruanos (APCH 2004: 20). Wilma Derpich afirma que a fines

Uno de ellos, Aurelio, falleció de niño.

2 En la partida de nacimiento de mi abuelo, inscrito en la Legación de China, figura como original de la provincia de Fukien, pero los lugares no corresponden con las comarcas de la actual Fukien. Según Wikipedia Fukien es una provincia archipiélago con sólo dos departamentos.

3 Certificado del Consulado de la República China en Lima y Callao, y está firmado en 1921. del XIX coexistían dos tipos de migrantes chinos: los pobres y los ricos “... que sostenían, en pequeña y gran escala, ejes, exitosos de la economía y sociedad peruana" (Derpich 1999: 19) ${ }^{4}$. Sería interesante realmente conocer con precisión cuál fue la labor de mi bisabuelo como comerciante y, en caso de haberlo sido, también como funcionario del consulado chino en el Perú.
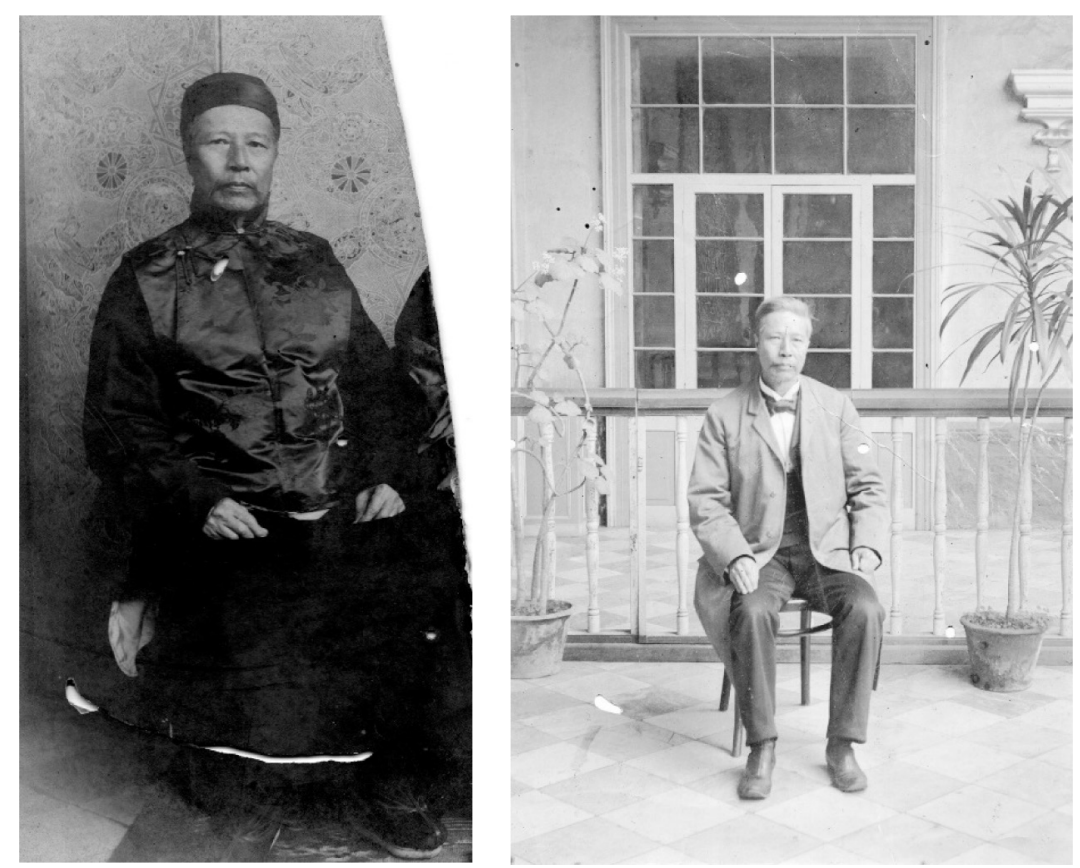

Foto 1: Carlos Chang Yeck Ting (China 1836 aprox.- Lima 1926).

La partida de bautizo de mi abuelo registra que mi bisabuelo provenía de Cantón 5 . Según Humberto Rodríguez Pastor, allí en 1856 fue el inicio de la Segunda Guerra del Opio. La primera Guerra del Opio o la primera guerra anglo china fue un conflicto bélico que enfrentó al Reino Unido y al Imperio Chino entre 1839-1842. El conflicto estalló ante la decisión del gobierno imperial de China de endurecer las medidas contra el tráfico ilegal de opio que narcotraficantes británicos practicaban con relativa impunidad en la China ${ }^{6}$. Este comercio ilegal de la

4 Cfr. APCH 2004 p. 23.

5 También encontrado por Humberto Rodríguez Pastor en el marco del proyecto Chinos 2000-2004 en el archivo arzobispal, figura el nombre de mi bisabuelo como Carlos Yektin, natural de Cantón, y el bautizo de Federico en la parroquia del Sagrado Corazón de María (Los Huérfanos), nacido el 18 de julio de 1887.

6 En 1839 el emperador Daoguang ordenó la incautación de todo el opio en manos extranjeras en Cantón. Esto causó una escalada del conflicto comercial entre China y el Reino Unido a lo largo de 1839, que devino en una declaración de guerra formal en el verano 
India a la China se había posicionado y permitido a Inglaterra equilibrar la balanza comercial por la compra de productos de la China. El imperio entra en conflicto con el gobierno británico por lo que el Parlamento Británico en el gobierno de la reina Victoria le declara la guerra, lo cual originará la ocupación inglesa de Hong Kong 7 , con ello pierde su soberanía y termina la era de las dinastías en China.

En Cantón a fines de 1856 se produjeron incidentes entre ingleses y la gobernación. Estos acontecimientos, según informó el cónsul peruano, ocurrieron a partir de las tropelías cometidas por los chinos contra los ingleses; los primeros tenían el apoyo del "alto comando imperial Yeli" (Rodríguez Pastor 2019: 49). Así, incendiaron las factorías establecidas por los europeos. El fuego consumió una caja que contenía los legajos del archivo del anterior cónsul, Domingo Sañudo, quien se vio obligado a abandonar el centro poblado. Por eso no quedó nada del anterior ejercicio consular especialmente lo referente a la emigración de chinos (Rodríguez Pastor 2019: 49). Según el autor, a ello se sumó: "la paralización de todas las transacciones y una carestía jamás vista”. Además:

Los ingleses esperaban refuerzos de la India para ocupar todo el poblado de Cantón. Ubicaron la mayor cantidad de sus fuerzas navales en el río Zhu Jiang (de las Perlas), inminente para un ataque, además de dos vapores y una guarnición de tierra. Antes de ello, los chinos hicieron fuego contra botes de la Unión Americana por lo que se unieron norteamericanos e ingleses y demolieron los fuertes chinos; pocas semanas después se unieron los franceses quienes habían sido atacados por naturales, quienes atacaron la tripulación de un barco francés que había zarpado con culíes en dirección a la Habana. Los levantados mataron al capitán el piloto y el sobrecargo, la tripulación,

de 1840. Los británicos aprovecharon su superioridad naval para forzar la rendición de China, que cedió Hong Kong a los británicos y accedió a abrir al comercio con Occidente varios puertos de China. Tomado de Wikipedia, consultado 20 de enero de 2020.

7 En 1995, el director chino Xie Jin propuso realizar una película que recreara el momento histórico en que Hong Kong perdió su soberanía en manos de la reina Victoria. Su propuesta fue aceptada, pero con la condición de que el gobierno chino no interviniera en la financiación, para así garantizar que el filme no se utilizaría con fines propagandísticos. Financiada por bancos chinos y británicos, la película se estrenó en las principales ciudades asiáticas el mismo día en que Inglaterra devolvió Hong Kong a China. Tomado de https:// www.abc.es/play/pelicula/la-guerra-del-opio-1426/, consultado 15 de enero de 2020. y luego sólo llegaron a Tong-Lac a 20 millas. La intención de los europeos era obligar a los chinos a que faciliten el comercio de exportación de sus riquezas al interior para penetrar la civilización en sus vastísimas regiones (Rodríguez Pastor 2019: $50)$.

En 1858 se firmó el tratado de Tiajin entre el Imperio Chino, de un lado, con Gran Bretańa, Francia y Rusia, que puso fin a la Segunda Guerra del Opio, una demostración de la fuerza de los poderes imperialistas occidentales en un doble sentido, no sólo autorizaba la injerencia en la economía china, sino que además permitía la imposición de una determinada política del consumo (principalmente del opio), que suponía arrebatar a la administración Qing su soberanía política (Cantón 2016: 391). Es importante mencionarlo porque si el origen de mi bisabuelo fue Cantón, es posible que la denominada Segunda Guerra del Opio tuviera un impacto en las condiciones de vida de él y su familia antes de su partida hacia el Perú.

El documento que certifica la inscripción de mi bisabuelo como comerciante de origen chino, nacido en Cantón, está sellado por la sección de pasaportes de Lima y Callao del Consulado de la República China. Ese tipo de relación consular se fue fortaleciendo con el comercio de culíes que luego se convirtió en el de chinos libres. Una referencia concreta sobre el tema, señala Humberto Rodríguez Pastor, es la existencia de un agente diplomático peruano en Cantón. Buscando las conexiones con la historia de mi bisabuelo, encontré la explicación de una de las funciones administrativas de los cónsules que era la obligación de no dejar que ningún buque nacional saliera del puerto en el que ellos residían sin que tuviera licencia o pasaporte (Rodríguez Pastor 2019: 74). Ello estuvo relacionado con el acuerdo de comercio que se estableció después que China tuvo que abrir sus puertos a barcos extranjeros, tras el conflicto entre Inglaterra y China, y por tener como destino a Perú en la ruta de la trata amarilla. En el Perú en abril de 1877 se realizó un contrato por cinco años con la Olyphant y Co. de Hong Kong, por el que se cambiaría nitrato por un gran número de culíes $(28$ viajes trayendo cada uno no menos de 500 culíes), entre las condiciones estaba que se trataría de chinos libres que vinieran por propia voluntad en condición de simples pasajeros (Rodríguez Pastor 2019: 75). 
Desconocemos si el bisabuelo tuvo alguna relación con este tipo de intercambio comercial o de trata. Sin embargo, esta fue una de las rutas de comercio e intercambio frecuente para llegar al puerto del Callao en el Perú; y la otra fue para el de la Habana en Cuba. Alguna de estas rutas comerciales, que fueron antecedentes de las relaciones comerciales y consulares entre Perú y China, debió seguir mi bisabuelo para llegar al Perú, en el caso de haber partido de Cantón ${ }^{8}$.

En los años en que estaba estudiando en el colegio $^{9}$, un día mi tío paterno le comunicó a mi padre que un amigo que revisaba el diario El Comercio cotidianamente había encontrado la noticia en la sección Sucedió hace un siglo una referencia sobre la llegada de mi bisabuelo al puerto del Callao, pero se lo dijo un tiempo después de publicado por lo que no llegó a encontrarlo. Mi hermana, quien trabajaba en una sección del Comercio por esas fechas, intentó buscar la referencia, pero no tuvo los datos exactos y por lo tanto no la encontró. La noticia, según la referencia de mi tío, decía que había llegado en barco desde Inglaterra como diplomático de China, el nombre de mi bisabuelo, (Carlos) Chang Yuk (Yek) Ting y sus señas particulares. Esta es otra hipótesis sobre la llegada de mi bisabuelo, que sostiene que salió directamente luego de haber residido o visitado Inglaterra. La referencia de la fecha de hallazgo de esta noticia es aproximadamente de

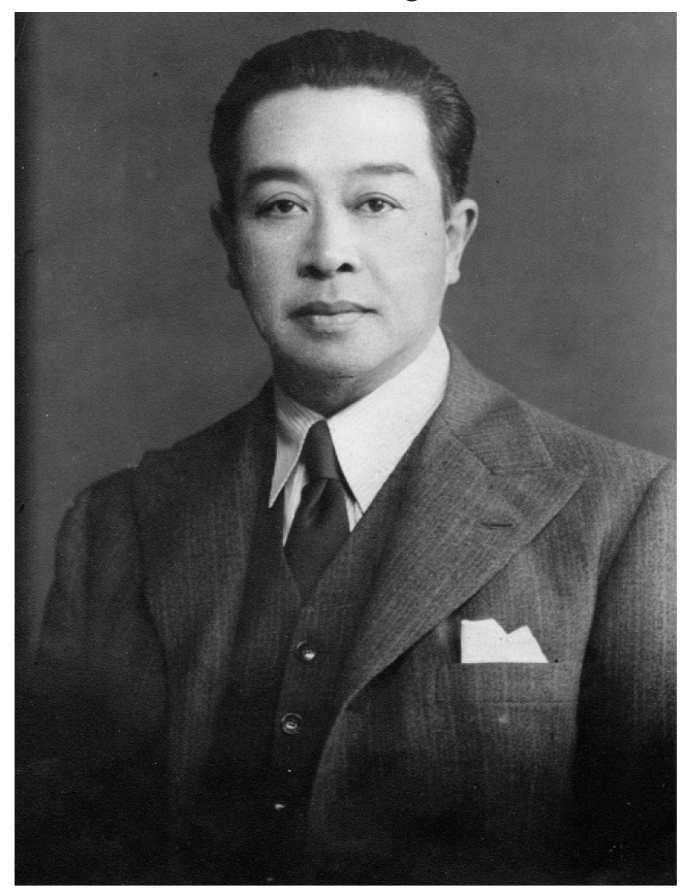

Foto 2. Emilio Federico Yeckting Arana (Lima 1887-1974) a la edad de 25 ańos. En el documento se consigna "de padres infieles" y como padrinos inscribió a sus suegros $^{10}$. Él se casó con Regina Arana Ponky, al parecer, también de origen chino. Seguramente, realizó el bautizo para que no lo tilden de infiel, y como muestra de ciudadanía, ya que la iglesia y la comunidad podían discriminarlo por no estar bautizado, según la tradición de la época ${ }^{11}$. De mi bisabuelo se recuerda poco. Según mi tío:

De mi abuelo solamente las fotos que yo he visto, una foto con su kimono (sic) ${ }^{12}$ [...] y que su papá había venido como diplomático, que era secretario de la embajada de China en el Perú y que tenía la fábrica de cigarrillos. ${ }^{13}$

Según mi tío, mi bisabuelo fue el dueño de una de las primeras fábricas de cigarrillos del país. La cual tenía como nombre el apellido Yuk (Yeck) Ting con una imagen que se perdió en el recuerdo. El cuadro de la imagen del logo de la fábrica de cigarrillos de mi abuelo se lo robaron o se extravió en la oficina de mi padre y mi familia no conservó ninguna copia. Sin embargo, mi familia tiene un recuerdo de la existencia de dicha imagen.

Mi abuelo nació en Lima en julio de 1887 y su niñez la pasó junto a sus padres, mi bisabuelo y bisabuela. De adulto fue un hombre carismático, sociable y amigable, finales de los años 80. ¿Por qué llegó? ¿Cómo un joven de 24 o 25 años llegó de la China a trabajar o a inscribirse como súbdito y comerciante en el Consulado de China en el Perú? ¿Cuál fue su verdadero vínculo con el imperio Chino de la época?

Conozco el nombre de mi bisabuelo porque luego de una intensa búsqueda, mis tías encontraron los documentos que certifican el bautizo de mi bisabuelo

9 Debe haber ocurrido aproximadamente en 1989.
10 El bautizó se realizó en la Parroquia de Santa Ana el catorce de mayo de 1926.

11 Entre las pertenencias de mi bisabuelo se encontraba un libro de catecismo en chino editado por la Asociación de Católicos Chinos del Sagrado Corazón de Jesús, de la Iglesia de San Pedro en 1950.

12 Podría tratarse del traje tradicional elegante generalmente de varones, Changshan, se instauró al final de la dinastía Qing (XVII-XX, finalizó en 1912), fundada por los manchúes, está formado por unos pantalones y una chaqueta llamada tangzhuang. Puede ser de diferentes colores. Se utiliza para eventos importantes como el Ańo Nuevo o las bodas. También se utiliza en los entierros, ocasión en que se utiliza el changshan y un sombrero negro. Fuente: https://www.viajejet.com/ traje-tipico-china/, consultado 20 de enero de 2020.

13 Entrevista a mi tío paterno, 13 de octubre de 2019. 
que además tocaba guitarra, bandurria y mandolina. Los tres instrumentos los tenía en su casa. La guitarra era española y había sido un obsequio. De joven formó parte de un conjunto, que en esa época le llamaban estudiantina, cuya conformación era principalmente de músicos que tocaban instrumentos de cuerda. Luego se casó con mi abuela, y tuvo cinco hijos, tres mujeres y dos varones. Toda la familia vivió en Barrios Altos, en el condominio llamado el buque. Mi tío recuerda:

La casa existe, es lo que lo llaman el buque ${ }^{14}$, claro que en ese tiempo era una residencia, [estaba] enterita, era una zona residencial. Me parece que nosotros vivíamos en el tercer piso. Me acuerdo que tenía un balcón que hasta ahora se conserva en ruinas. Por allí nos asomábamos y veíamos como mi papa tomaba el tranvía cuando se iba... ${ }^{15}$

Los estudios de mi tío y mi padre comienzan con las primeras letras, lo que ahora sería un jardín (educación inicial), ubicado en Barrios Altos. Luego vivieron en Pueblo Libre la mayor parte de sus vidas hasta jóvenes. Allí mi tío y mi padre estudiaron en colegio parroquial de varones Claretiano; y las mujeres en el colegio de monjas religiosas Santa Ana de San Miguel.

El abuelo fue "administrador de fincas". El administraba y hacía la cobranza de un conjunto de propiedades en alquiler de determinadas familias que representaban a la denominada aristocracia limeña, como los Eguiguren, los Marsano, o los Torrico de Lima, a quienes conocía. Como administrador cobraba el alquiler y gestionaba el mantenimiento. Además, realizaba el pago de los impuestos y cuidaba el estado de las fincas, a cambio de un porcentaje que recibía por la cobranza. Al principio esta actividad fue bastante rentable. Según mi tío, mi abuelo tenía los recursos necesarios para el mantenimiento de los inmuebles a su cargo, una cuadrilla de trabajadores, que hacían reparaciones: pintores, y entre ellos, un gasfitero, que trabajaba con él para tener en buen estado las propiedades.

Probablemente, debido a que mi bisabuelo había sido comerciante y también funcionario del consulado chino, mi abuelo tenía una gran habilidad para

14 Cerca del monumento de la piedra horadada en Barrios Altos.

15 Entrevista a mi tío paterno, Lima octubre de 2019. relacionarse con las familias acomodadas y personajes célebres de la época. Es por ello que alquiló una oficina en el Jr. Puno, donde atendía a sus clientes.

Debo reconocer que durante mi niñez no era muy consciente de mis orígenes chinos, a excepción de una que otra referencia en mi familia, y casi poca memoria en cuanto a la pertenencia a una comunidad chino-peruana o tusan. La reconstrucción de la memoria presentaba dificultad también por la inexistencia de algunos documentos que, con las constantes mudanzas de mi familia y necesidad de no acumular papeles, mis tías desaparecieron porque según ellas "no sabian que alguien podría interesarle y menos que yo iba a ser antropóloga". Los documentos del origen de mi bisabuelo y abuelo que poco a poco empezaron a encontrar mis tías, han sido muy valiosos para comprender una parte importante de mis orígenes, junto con algunas fotos por las que ahora conozco la apariencia de mi bisabuelo y abuelo.

\section{Recuerdos de la oficina de mi abuelo y de mi padre}

Ricouer se refiere a la relación entre la memoria y los espacios que denomina como los lugares de memoria. Sostiene que, los desplazamientos del cuerpo e incluso su permanencia en el lugar no se dejan expresar ni pensar, ni siquiera, en última instancia, experimentar, sin alguna referencia, al menos alusiva a los puntos, las líneas, las superficies, los volúmenes, las distancias, inscritos en un espacio separados de la referencia del aquí y el allí, inherentes al cuerpo propio. Entre el espacio vivido del cuerpo propio, y del entorno y del espacio público, se intercala el espacio geométrico (Ricoeur 2004 p. 193). Es por ello que abordaré los recuerdos de las oficinas de mi abuelo y de mi padre como lugares de memoria.

La oficina del recuerdo familiar estaba en el Jr. Puno, en el Cercado de Lima. Según mi tío, aquella oficina tenía una división en el segundo ambiente que se habilitó para el alquiler de un abogado. Mi tío recuerda que mi abuelo inicialmente había tenido una oficina en la cuadra anterior al Jr. Puno, en la calle Bejarano. Tuvo que dejar la oficina y se mudó. Allí iban los inquilinos a pagar directamente, pero pocos. Los inquilinos más numerosos que tenía estaban en la calle de la Confianza, un callejón en el 
sótano adonde mi abuelo iba a realizar las cobranzas. Después los que iban eran los trabajadores que mi abuelo contrataba para el mantenimiento de las casas. Mi tío dice: "Yo no sé cómo mi papá se relacionaba con esas personas por decirlo de alguna manera de 'buena familia" "16. Uno de ellos fue Luis Antonio Eguiguren ${ }^{17}$, candidato a presidente de la República que obtuvo la elección, pero por poco tiempo, porque fue desconocida, por lo que se convirtió en un presidente circunstancial.

Entre los diferentes personajes a quienes conoció, mi abuelo, era amigo personal de Pedro Dulanto, quien fue rector de la Universidad Nacional Mayor de San Marcos entre 1948 y 1952 hasta antes de su muerte ${ }^{18}$. Mi abuelo administraba las tiendas de Dulanto que tenía en el Rímac. Según mi tío, el trabajo de mi abuelo sirvió para mantener a la familia: Nosotros hemos podido mantenernos con eso no más, con la administración de mi papá, éramos de clase media ${ }^{19}$. Ello sirvió para que la familia viva de los ingresos de mi abuelo, y especialmente los hijos e hijas accedieran a una educación básica, primaria y secundaria, además de técnica y superior. Mi padre estudió contabilidad y mi tío ingresó en la Universidad Nacional de Ingeniería y realizó una carrera como ingeniero. Mientras que mis tías tuvieron formación secundaria y técnica, y trabajaron en labores administrativas.

Mi papá heredó la profesión de mi abuelo, continuó con esa labor, aún con las posibilidades, no optó por una carrera universitaria. En la oficina de mis recuerdos del Jr. Puno, a la que fui cuando tenía siete u ocho años, mi papá iba sólo esporádicamente allí, sobre todo para pagar el alquiler a la Srta. Margarita, ya que los dueńos de toda la casa eran la familia Eguiguren. La oficina estaba prácticamente cerrada,

16 Entrevista a mi tío, octubre de 2019

17 Luis Antonio Eguiguren Escudero, (* Piura, 21 de julio de 1887- $\dagger$ Lima 15 de agosto de 1967) fue un magistrado, historiador y político peruano. Fue director del Archivo General de la Nación(1914), Regidor de Lima (1914-1920), Alcalde de Lima (1930), Presidente del Congreso Constituyente (1930-1932), fundador y líder del Partido Socialdemócrata. Obtuvo la victoria en las elecciones presidenciales de 1936, pero tal elección fue desconocida por el Congreso Nacional y el entonces Presidente Óscar R. Benavides, aduciendo que había ganado con votos apristas. Presidió la Corte Suprema y el Poder Judicial en 1953 y 1954. Fuente Wikipedia consultado 14 de octubre de 2019.

18 Pedro Dulanto Monterola (Chancay, Departamento de Lima, 1889 Lima, 19 de noviembre de 1952) fue un abogado y político peruano, rector de la Universidad de San Marcos. Fuente Wikipedia consultado 14 de octubre de 2019

19 Entrevista a mi tío, 13 de octubre de 2019. pero recuerdo vagamente alguna imagen de esta oficina al interior de una casa antigua. Aquí parecía que se había detenido el tiempo, creo que mi papá me llevó sólo una o dos veces, recuerdo los sillones verdes forrados en plástico, el piso de madera y en lo alto de la pared frente al escritorio también de madera, el cuadro con el dibujo de una marca, un logo, o símbolo, probablemente, el de la fábrica de cigarrillos.

\section{La contabilidad como trabajo y el ábaco}

Para llevar la contabilidad como administrador, mi abuelo tenía dos ábacos, uno en su casa y el otro en su oficina, que utilizaba con destreza y dominaba para realizar las cuentas, además de sus libros de contabilidad. Según una de mis tías ${ }^{20}$, dedicada a la administración, el abuelo era muy hábil en el dominio del ábaco, él trató de enseñarle su uso a ella, pero al principio le pareció muy complicado. Como datos, el ábaco chino tiene más de 1,000 ańos de antigüedad, no se sabe cuándo fue creado, se atribuye a los 500 a.d.c., fue utilizado y expandido por las culturas orientales, especialmente China y Japón. Se desarrolló aún más o se hizo famoso durante la edad media de China, durante la etapa de la dinastía Ming (13681644). Se señala que el ábaco chino es utilizado para operaciones de cálculo simples como sumas, restas, multiplicaciones y divisiones; y luego se amplió para sacar raíces cuadradas y raíces cúbicas.

La reseña que encontré dice que es útil para realizar cálculos y operaciones rápidas. Eso me recordó que mi padre era bueno con los números y sabía hacer operaciones rápidas con ellos, sumas y restas al revés, operaciones con los nueves, regla de los cinco para las multiplicaciones y hasta un truco con la raíz cuadrada que imagino provenía de ese conocimiento transmitido de mi abuelo con los números y sus habilidades en el uso del ábaco. Los ábacos eran de mi abuelo, probablemente su padre le enseñó a usarlo. Mi abuelo le enseñó a usar el ábaco también a mi papá, que le quiso enseñar el uso del ábaco a mi hermana. Luego mi abuelo le enseñó a usar el ábaco a su nieto, mi primo, quien vive en EEUU, y hace poco pidió que le llevaran el ábaco para tenerlo, porque lo sigue utilizando, con él multiplica, suma, y resta. Mi

20 Entrevista a mi tía, 12 de octubre de 2019. 
abuelo dominaba el ábaco y mi primo desde que lo vio utilizándolo le dijo que le enseńara. $\mathrm{Al}$ respecto, mi tío comentó: nosotros lo usábamos para jugar, pero mi papá nos dejaba, aun cuando era su herramienta. La costumbre del uso del ábaco venía de los chinos [... $]^{21}$. Era una costumbre que se transmitió de generación en generación y parece que era algo común en la época ver los negocios y tiendas con dueños y administradores de origen chino con su ábaco.

El hermano de mi abuelo, Isaac, trabajó como supervisor de las obras de las carreteras en el gobierno de Leguía en 1920. Durante la etapa de la ley de conscripción vial, mi tío abuelo, se fue primero a vivir a Huánuco y luego estuvo en Lima supervisando el trabajo de las cuadrillas en las carreteras. Luego trabajó en las empresas eléctricas también como jefe o supervisor. Tuvo sólo una hija. Mi tío abuelo vivió con su hermano y su familia, la mayor parte de su vida. Vivieron en casas alquiladas. Según mis tías, era difícil conseguir casas en alquiler que tuvieran espacio para una familia de nueve o diez integrantes.

\section{Recuerdos de mi padre y sus tradiciones de origen chino}

Un hecho ineludible en mi familia es el tema de la celebración a través de la comida, que creo que todos los tusans compartimos. El ritual de comer la comida china o de la fusión chino peruana ${ }^{22}$ era siempre un motivo de celebración. Con los años me di cuenta que no todas las familias celebran el cumpleaños de cada miembro con ir a comer al chifa, o mejor aún con preparar con dedicación un exquisito buffet de comida fusión chino peruana para su cumpleaños. Mi papá en sus andanzas en el centro de Lima, y seguramente porque sus genes lo llevaron a eso, había conversado con los cocineros del barrio chino para que les cuenten sus secretos. Según se relata, en 1921 se inaugura en la calle Capón el primer chifa El Kuong Tong (que significa Cantón) logró introducir en los limeños el hábito de comer potajes chinos gracias a la gran acogida que alcanzó una de sus preparaciones

21 Entrevista a mi tío, 13 de octubre de 2019.

22 Es innegable la influencia de la comida cantonesa, que se caracteriza por el uso de carnes como cerdo, pato o pollo, más que los platos de otras provincias de la China, realizados sólo con verduras, y su fusión en el chifa peruano. en base a abalones (verdura china), hongos chinos y gallina, y que el ingenio criollo bautizó después como "taypá" (APCH 2004: 40). El conocimiento y disfrute de la comida china se expandió a través de los años y en diversas partes del país.

Mi padre, según recuerdo, era el mejor en preparar un exquisito buffet que presentaba en extenso en la mesa del comedor de mi casa para su cumpleaños. Para ello se preparaba con mucha anticipación. Realizaba las compras de las verduras y productos chinos en el mercado de Magdalena porque nosotros vivíamos en San Miguel, y por supuesto, yo siempre lo acompañaba y ayudaba en la preparación. El ritual de la preparación consistía en hacer desde los wantanes, cocidos para la sopa wantán, y fritos para el kan lu wantán, hasta seleccionar las verduras para el tallarín saltado, la carne, el pollo, el pato y el chancho, para el suculento asado que preparaba, adecuando el pequeño horno que teníamos en la cocina de la casa. Todo ello acompañado de su respectivo nabo encurtido, y no olvidaba también preparar el postre de las naranjitas chinas ${ }^{23}$. Era un excelente cocinero de chifa, se sabía todos los secretos. De lunes a viernes mi padre no cocinaba usualmente, ni tampoco preparaba otro tipo de comida, sólo chifa. Pero para su cumpleaños, preparaba todo un banquete como parte de una celebración que esperábamos en familia.

Sin embargo, había olvidado mucho de estos orígenes o de las características de mi padre o de mi familia paterna, cuando ya de joven un día fui a ver la película El baño, también conocida como la ducha ${ }^{24}$. Esa película despertó en mi algo de mi memoria cultural, reflejos de las características de la cultura de origen que pensaba eran particulares de mi padre, pero que la película me ayudó a entender que eran más bien culturales. La película es la historia de un joven cosmopolita que trabaja en un banco en Hong Kong y que de pronto se ve en la necesidad de ir a visitar a su padre que vive en su localidad de origen tradicional, además de cuidar a otro de sus hijos que sufre un retraso mental, donde administra un baño donde van los varones del pueblo para relajarse, contarse sus

23 Postre realizado con "naranjitas chinas", más pequeñas que las tradicionales que existen en el mercado nacional, puestas en almíbar.

24 Película china "Xizao" (traducida como El baño, o La ducha) del año 1999 y dirigida por Zhang Yang y premiada con la Concha de Plata al mejor director del Festival de Cine de San Sebastián. 
problemas y conversar entre ellos ¿Cuáles eran estas características?

La película presenta los rasgos de la transmisión de valores comunitarios del padre, su vínculo directo con sus clientes y el hecho de asegurar el valor del trabajo como una forma de vida, y cómo se involucra con cada uno de ellos, a partir de su capacidad de escucha y de búsqueda de solución de sus problemas, por medio de valores como la solidaridad, la confianza y también el arraigo a la tradición familiar como base de la identidad comunal de origen. Mientras en la película el hijo le transmite al padre la necesidad de olvidarse de la tradición y perder el baño que va a ser comprado por una constructora y también debido a su vejez, el padre se resiste y trata de involucrar al hijo en las costumbres de la comunidad para que se quede en el pueblo. Estas características, como la transmisión de ciertos valores, la vocación de servicio, el estar allí para su familia y amigos, en mi percepción, podrían habérsele atribuido a la personalidad de mi padre. En la película se presentaban como parte del dilema de la supervivencia de la tradición cultural frente a las transformaciones que implicaban nuevas formas de vida cosmopolitas en una China contemporánea o actual. Lo cual también se veía reflejado en la costumbre de preparar e invitar la comida. La costumbre china de invitar a comer es brindar la confianza y también un gesto de proximidad ${ }^{25}$. Estos aspectos de la identidad cultural china también se relacionan con las tradiciones andinas.

Mi tío cuenta que si nuestros orígenes chinos estuvieron cubiertos o velados es porque hubo un tiempo, probablemente después de la Segunda Guerra Mundial, en el que se producía la discriminación por la imagen de los chinos que se asociaba a la esclavitud, y también por la asociación con la identidad japonesa. Entonces lo asiático se unificaba; y, a su vez, se menospreciaba. Así cuenta, la impresión que tuvieron cuando la población atacó la tienda de un

25 Otra película relacionada con el tema de la comida de origen chino es Comer, Beber, Amar, de Ang Lee. El director hace en este filme un excelente y conmovedor retrato de la vida del maestro cocinero Chu (Si Hung Lung), semiretirado y viudo, y su familia, compuesta por tres hijas, que viven en el moderno Taipéi en Taiwán, y que están en un punto de quiebre debido a sus diferencias personales y la ominosa presencia de la modernidad, que ha comenzado a socavar las raíces de la familia taiwanesa tradicional. Tomado de Wikipedia, consultado 15 de enero de 2020. vecino japonés de apellido Kanashiro, cuando vivían en Pueblo Libre.

Antes también no eran bien vistos los chinos, había un menosprecio, es que los confundían con los japoneses, y había un odio contra los japones, probablemente por la guerra, no eran delincuentes, pero sí se veían como esclavos, se relacionaba con la esclavitud, como el indígena peruano. Cuando comenzó la guerra, los locales de los japoneses los apedrearon. Incluso nosotros vivíamos en el Jr. Junín y allí en la esquina, había un japonés, Enrique Kanashiro, que era muy buena gente, pero le saquearon el local... ${ }^{26}$

Esa actitud fue una constante a través de la historia de migración en el país, en que la población de diferentes orígenes extranjeros fue discriminada y por la que se estigmatizó a los de origen asiático. Afortunadamente, no he sido discriminada por ser de origen chino y más bien me he empeñado en hablar de mis raíces y de los prejuicios que hay frente a la población migrante de origen asiático en el país. Recuerdo que en una ocasión le dije a mi padre que en el colegio debería hablar más sobre mi origen chino, y su respuesta fue "será para que te digan que eres hija del chino de la esquina". Una expresión bastante significativa de la percepción de la época. Ello responde a que la experiencia en la administración de comercios como los tambos, un lugar vital de la hacienda, como cantina, café o tienda, y su innato espíritu comercial, llevaron a los migrantes chinos, algunos culíes liberados, a establecer tiendas conocidas como el del "chino de la esquina", estableciéndose primero en pequeńas bodegas para la venta de abarrotes al menudeo en zonas comerciales. De esta manera, se formó el germen de lo que es hoy la calle Capón, en el Cercado de Lima (APCH 2004: 20). Luego estas bodegas de barrio y comercios se expandieron por todos los distritos de Lima.

La generación de mi padre en mi familia se había acostumbrado a no hablar mucho de sus orígenes chinos, aun siendo visibles por las características físicas. Para mí, el ser antropóloga, me enseñó más sobre el orgullo de mis raíces y a interesarme por la filosofía y conocimientos de la tradición cultural china. Percibo que mi generación, primos y sobrinos, transmitimos con mayor libertad que teníamos como origen la identidad cultural china con un genuino y legítimo 
interés por conocer nuestras raíces. En mi caso, más aun, por la necesidad de saber si existe alguna rama de mi árbol familiar en la China que sepa o conozca más de los avatares de la vida de mi bisabuelo que lo llevó a cruzar el pacífico con dirección al Perú.

\section{A manera de epílogo}

Las conclusiones sobre los orígenes chinos de mi familia parten de los recuerdos de la llegada de mi bisabuelo al Perú, de quien se recuerda fue un funcionario del consulado de China, pero no está completamente claro que hacía antes de enrumbarse hacia el Perú, ni de donde vino. Es posible establecer una hipótesis sobre la información de los recuerdos encontrados que señalan que llegó luego de estar (o estudiar) en Inglaterra. La otra hipótesis es que salió directamente de la China, ya sea de Fukien o de Cantón. Pero no se conoce con exactitud qué vínculo tuvo con las relaciones comerciales establecidas en el gobierno con el Consulado de Perú en la China, e inclusive con los acuerdos comerciales de trata o comercio de culíes que, a cambio de productos, sostuvieron ambos gobiernos. Probablemente, el contexto histórico de la época de la segunda Guerra del Opio, que se sostiene volvió imposible la vida en la China, haya determinado que mi bisabuelo saliera de su país a buscar mejores condiciones de vida, y por esa razón, haya cambiado u omitido los datos de sus orígenes en los documentos, o que hayan sido mal interpretados, al igual que la caligrafía de su apellido, por los funcionarios encargados de los registros oficiales.

Sobre mi abuelo, los documentos y testimonios de mis tíos muestran que coinciden en que sus recuerdos son a partir de su vida, la familia que formó, y su labor como administrador. Recordamos sus habilidades con el ábaco y, especialmente, como administrador de las fincas que tuvo a su cargo, por la confianza que le tenían personas de familias acomodadas con quienes se relacionaba como administrador. Hasta el momento desconocemos si los vínculos de mi bisabuelo y/o sus habilidades como comerciante entrenaron a mi abuelo en establecer relaciones sociales.

Los rasgos de las tradiciones de la cultura china que se pueden rastrear en la niebla de la memoria de mi familia están basados en las raíces de mi abuelo, la vestimenta, costumbres que tuvo, y el idioma ${ }^{27}$, que no fueron transmitidos; o elementos como: el uso del ábaco, los valores y la tradición cultural de la comida cantonesa, que si fueron transmitidos y redescubiertos por mi padre como parte de las conmemoraciones, y que tienen su origen en la cultura china. Es importante señalar que muchos de estos valores fueron ocultados e invisibilizados por la discriminación en el contexto de la Segunda Guerra Mundial. En el Perú se atacó y expulso a familias de origen japonés que motivó la discriminación a todos los descendientes de origen asiático. También por la situación de explotación y marginación que sufrieron los culíes como población migrante en condición de servidumbre. Tuvo a Asia y específicamente el Japón como referentes, y porque la población en general empezó a discriminar desde el siglo XIX y luego en el XX hasta perseguir a los migrantes o descendientes de origen asiático. Esta transmisión de valores y aspectos de los orígenes una vez desentrañadas crean en mi generación un legítimo interés en conocer nuestras raíces y las motivaciones en la vida de mi bisabuelo para llegar al Perú. Algo de lo que queda mucho por profundizar y descubrir.

\section{Bibliografía}

Asociación Peruano China (2004). De la misma raiz. Memoria 1999-2004. Lima: Graffiti Promotores Unidos S.A. APCH. 2004.

Cantón Alvárez, José Antonio (2016). «Opio y colonialismo: reflexiones sobre el papel del opio en la penetración colonial europea en Asia y China». Opio, China, colonialismo, Asia, sinocentrismo. Estudios de Asia y África Universidad de Granada Li 2016: 2. pp. 391-412.

Derpich Gallo, Wilma (1999). El otro lado azul. Empresarios chinos en el Perú (1890-1930). Lima, Fondo Editorial del Congreso del Perú.

Rodríguez Pastor, Humberto (2017). Chinos en la sociedad peruana 1850-2000. Presencia, influencia y alcances. Universidad Nacional Mayor de San Marcos. Fondo Editorial Facultad de Ciencias Sociales. Lima, setiembre de 2017.

27 Es posible que mi bisabuelo estudiara otros idiomas como el inglés y el español antes de su viaje al Perú. 